\title{
Analysis of the bilateral trade between gulf cooperation council countries
}

\author{
Akram Masoud Haddad ${ }^{\text {* }}$

\begin{tabular}{l}
\hline C H R O N I C L E \\
\hline Article history: \\
Received: June 152019 \\
Received in revised format: June \\
152019 \\
Accepted: July 10, 2019 \\
Available online: \\
July 10, 2019 \\
\hline Keywords: \\
Bi-lateral trade \\
GCC countries \\
International trade \\
Intra trade \\
Regional cooperation \\
Trade zones \\
\hline
\end{tabular}

${ }^{a}$ Professor of economics, Associate Dean, College of Business Administration, American University in the Emirates, UAE

\section{A B S T R A C T}

The Gulf Cooperation Council (GCC) countries economy is one of the biggest economies in the world with high per-capita income and high purchasing power. Although the member countries exhibit similarity in production, the GCC takes many steps to facilitate the intra-trade. The objective of this study is to analyze the intra-trade of the GCC during the period 1995-2018 and elaborate the impacts of the main three stages in the intra trade agreements between the GCC countries by considering the main sages in facilitating the intra trade among GCC members. The result of the study shows that Bahrain is the biggest importer and exporter from the GCCC followed by Oman, United Arab Emirates, Saudi Arabia, Qatar and Kuwait. Still the trade GCC intra trade consists very small proportion from the total trade of the GCCC, with increasing trends over years of the study period, however the analysis shows that there is no impact of the trade arrangements between the GCCC in the case of the stage of the GCC customs union during 2003-2008 and the stage of common market after 2008 on the progress of the intra trade.

(C) 2019 by the authors; licensee Growing Science, Canada

\section{Introduction}

The Gulf Council Cooperation (GCC) consists of six countries including Saudi Arabia, Kuwait, United Arab Emirates, Bahrain, Oman, and Qatar. The Gulf Cooperation Council (GCC) established in 1981 as free trade area. The GCC countries (GCC countries) total area is (2.673) million square kilometer, (the largest country is Saudi Arabia with 2.25 million square kilometers representing $80.4 \%$ of the total area of the GCC, followed by Oman with 11.6\% and United Arab Emirates with 3.1\% and the smallest is Bahrain with $0.03 \%$ followed by Qatar with $0.4 \%$ and Kuwait with $0.7 \%$. The total population of the GCC countries is estimated to be 60 million in 2019 . The population growth rate is $3.37 \%, 4.13 \%$ and $2.47 \%$ for the total, citizens and non-citizens population, respectively. About $44.5 \%$ of the workers in GCC countries are foreign workers (see Table 1). GCC countries exhibit similar economics, social and political backgrounds in many aspects. Most of the GCC countries are oil producers with the largest crude oil reserves in the world representing $35.7 \%$ of the world's total oil; and their economy highly depends on oil and hydrocarbon industries as a source of income. About $73 \%$ out of the total export earning of the GCC countries are oil and gas and consist about $41 \%$ of its growth domestic product (GDP). Therefore, GCC countries exhibit highly concentration and similar export patterns.

\footnotetext{
* Corresponding author.

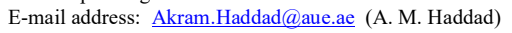


The GCC countries as group was the17th largest economy in the world in 2003, the 13th largest one in 2008, the 8 in 2011 and the sixth in 2016. The GCC countries are pursuing a highly open trade policy regime. Considering the economic and social factors (high income and larger purchasing power), GCC region is big market for services and goods. The GCCC is the $7^{\text {th }}$ rank in total trade with the amount of $\$ 1558$ million USD. The total export of the GCC region stays in the fourth rank among all counties with total export of $\$ 1024$ million USD, GCC region is the $15^{\text {th }}$ importer among the world countries, with an amount of (534.8) millions in 2014. One of the main objectives of the GCC economic agreement is to seek implementation of free trade region among GCC countries. However, economic integration within the GCC has been reinforced by the formation of the Customs Union in 2003 and the Common Market in 2008 as well as, the agreement to introduce a single GCC currency and become a monetary union by 2014. In attempt to achieve high intraregional integration and easiness the trade inflow among the member countries, the GCC countries have progressively lowered nontariff barriers, both as part of integration efforts and in response to commitments under the World Trade Organization (WTO). Significant progress has been made in establishing unified GCC technical standards covering more than three thousand products and harmonizing and reducing customs administrative procedures and clearance requirements. However, there are remaining nontariff barriers including preferential policies and practices related to public procurement requirements and subsidies to manufacturing industries, as well as continued customs border controls, which could result in tangible costs related to road transportation regulations and other ad hoc requirements.

Regardless of the various trade agreements among GCC countries, many studies show that the GCC intra-trade remains insignificant and reflects unsuccessful economic integration policies. This may due to similarities of economic structures, weak institutions, as well as the lack of industrial diversification. Therefore, the current study aims at analyzing the intra-trade of the GCC during the period 1995-2018 and elaborates the impacts of the main three stages in the intra trade agreements between the GCC countries mentioned above. To achieve this objective the following research questions is raised by this study:

1. What is the share of the GCC countries trade in the total international trade?

2. What are the commodities and country concentration and degree of diversifications trade in these countries?

3. What is the trend of the intra-trade of the GCC countries?

4. Explore some trade indexes of GCC countries.

\section{Review of Literatures}

There are many studies that evaluate the intra GCC trade during the last years using many economic and econometrical models. Dadush and Falcao (2009) concluded that to facilitate greater trade in goods, GCC countries must work to improve logistics and reduce non-tariff barriers to trade, the remaining big gains is from GCCC regional integration especially through increased integration of the service sector and improving administrative capacity. On the contrary, Akhtar and Rouis (2010) and Ravi (2013) found that the intra-regional trade of the GCCC is still at a modest level, and the trade intensity index shows negative signals except for the UAE, and Saudi Arabia. The study concludes that the unified economic policy of the GCCC has not achieved its target in terms of increasing the level of intra-trade which implies a high reliance on oil export revenues. Akhtar and Rouis (2010) found that the intraregional GCC trade flows remain relatively small despite strong growth in recent years. This figure compares unfavorably with other trading blocs such as ASEAN, NAFTA, and EU-15, reflecting weak complementarities among GCC member states and the relatively liberal trade regimes that had historically characterized the GCC economies. Nechi (2011) evaluated the intra-GCCC trade flows depending on the nature of goods and services performed, oil flows and non-oil flows and investigated trade determinants of both categories. The results show that excluded oil from trade flows, the GCC intra-trade becomes a significant proportion of total GCC trade flows so that GCC intra-trade is quite intensive and the GCC economies are more 
trade integrated than what aggregate data (inclusive of oil) may indicate. The gravity model which includes the traditional variables and indicators for the quality of infrastructure (roads, air transport, port efficiency, and telecommunication) shows that the quality of infrastructure is an important determinant of trade performance particularly the port efficiency appears to have the largest impact on trade among all indicators of infrastructure. Income levels, factor endowments, as well as level of development have significant effects on non-oil exports and non-oil imports. These results indicate that to promote trade integration policies, GCCC should maintain some additional measures including improving physical infrastructure and the efficiency of transportation systems needed to ensure low transportation costs.

Analysis of Intensity of intra-regional trade in GCCC during the period 1998-2008 accomplished by Abdul Sahib and Kari (2012) who found that the intra-regional trade is still at a modest level, where the trade intensity index showed negative signals except the UAE, and Saudi Arabia. The study concludes that the unified economic policy of the GCC countries did not achieve its target in terms of increasing the level of intra trade which implies a high reliance on oil export revenues. In recent years, the GCCC have been an attractive market destination for China, India, Japan and other Asian countries and huge interest exists in developing close relationships and doing businesses with GCCC and become a gate for the Middle Eastern markets. Malaysia, besides the religious affinity that it shares with the GCCC, is also highly interested in expanding its trade relations with these Arab Gulf Economies.

Insel and Tekce, (2010) analyzed the trade flows of the GCCC both among the member countries and with the rest of the world comparing trade for the 1997-2002 and 2003-2007 periods and explored the impact of Customs Union agreement of the GCCC in 2003. The results show that the order of top fifteen trade partners was changed significantly from the EU countries and the US to the Asian countries after 2003. The exports and imports of the GCCC were related to the wealth of the partner countries, not to their distance, this may due to the nature of their exported and imported goods, and the characteristic of the region and developments in transportation facilities.

\section{Methodology}

The study depends on the secondary data collected from national and international instructions such as UNCTAD Database and the GCC database. In addition, the study is based on an analysis of the data for the period 1995-2016. The data cover the exports and imports and some important indicators. For the sake of the study and considering that there are three distinguished stages in the history of the trade arrangements between the GCCC. We have added a dummy variable for the data which are associated with before 2002, 2003-2007 and after 2008, in linear regression for trends of the export and imports of each GCC countries.

\section{Results}

\subsection{Economics Environment facilitating intra-trade among GCCC}

According to the article four of the council charter (Peterson, 1988) basic objectives of the GCC are:

1. To coordinate, integrate and build an inter-connection between Member States in all fields in order to achieve unity between them,

2. To deepen and strengthen relationships, links and areas of cooperation now prevailing among their peoples in various fields,

3. To formulate similar regulations in various fields including economic, financial affairs, commerce, customs and communications, education and culture,

4. To stimulate scientific and technological progress in the fields of industry, mining, agriculture, water and animal resources; to establish scientific research; to establish joint ventures and encourage cooperation by the private sector for the good of their peoples. 
GCCC are members of the World Trade Organization (WTO) and other international and regional organizations as a single economic entity to improve the environment for trade, foreign investments and easy access conditions to world markets through unifying standards of GCC products. The intra-trade between the GCCC passed through many stages. These are:

1. Free zone stage (1983-2002).

After the establishment of the GCC in 1981 the GCC established a Free Trade Area in 1983. In this stage, According to Ayalon (1992), the most important issues accomplished to promote GCC intra-trade are:

a) to help GCC citizens involve in retail trade and wholesale trade equally,

b) to allow the GCC firms to open offices for commercial representation in any Member State and let them import and export national products from and into any Member State without a local agent in 1991,

c) to establish the GCC Commercial Arbitration Center (CAC) in 1995 based in Bahrain to provide an acceptable mechanism to settle commercial disputes, to addresse commercial disputes among citizens or non-nationals being natural or legal persons of the GCC. In addition, it addresses commercial disputes arising from implementing the economic agreements and their resolutions and to organize arbitration symposiums and seminars in GCC.

d) to establish the GCC Accounting and Auditing Commission (AAC) in 1998,

e) to establish the GCC Standardization Organization (GSO) in 2002. The GSO prepares, approves, and publishes GCC products' standards, unifies various standardizations and follows its application in cooperation and coordination with the standardization organizations in member states. This leads to develop production and service sectors, promote intra-GCC trade, protect consumers, environment and public health, and encourage GCC agricultural and industrial products, The GSO supports GCC economy and helps to reduce technical barriers on trade between the GCCC.

2. The GCC customs union stage during 2003-2008.

The GCC established customs union in 2003 aiming to eliminate the tariff and non-tariff barriers in order to facilitate intra-GCC flow of goods and to create a collective bargainer power for the GCC States to liberate trade with other international economic blocs, in addition to coordinating export and import policies. The GCC states enforce a common five percent tariff on imported goods across the region. In this stage the citizens of the GCC are free to move across borders and have the rights to employment and starting business in any state of the GCC. Unofficially, the union also coordinates various areas such as health, education, security and knowledge. According to (Peterson, 1988), this stage is characterized by:

a) Enhancing the rule of equal treatment accorded to GCC citizens by 2003 in different subject areas, such as involvement in retail and wholesale trade, trading share ownership, joint ventures establishment, mutual investment promotion and removing barriers to intra-GCC trade. Besides, Member States have tried to unify trade laws (GCC, 2016).

b) Implementing equal treatment to major GCC citizens in the field of stock ownership, business corporation and removing any possible restrictions in 2003.

c) Using the necessary common trade policies which unifies GCC external trade policy in 2005. This Policy is vis-à-vis other countries, with an aim to encourage trade and investment, expand markets, elevate GCC exports, and their competitive capacities and to improve the characteristics of the exports to world markets, and defend GCC products and services. In addition, this policy protects local markets and activates, the role of the private sector in helping GCC exports goods and services. Nevertheless, at the intra trade level the GCC unified trade policy tries at using an internal unified trade policy, which facilitate the movement of GCC citizens, goods, services among these countries, which could consequently improve investment and trade. 
Common market stage after 2008

This stage started with the GCC declared of common market status in 2008, which aims to create a single environment where citizens of member countries enjoy equal rights and privileges, including the rights to move, settle, work, receive social protection, retirement, health, education and social services, and engage in various economic activities and services. It also calls for unrestricted rights of ownership of property and equity, movement of capital, and similar tax treatment (Peterson, 1988). To facilitate, accelerate and provide suitable enabling environments for trade and internal trade among the GCC, the supreme council approves several issues such as adopting several laws and regulations, enhancing economic citizenship, and setting up mutual commissions during that period such as:

a) Permitting Gulf companies to have branches in the GCC countries and receive equal treatment similar to local companies in 2010.

b) Adopting some necessary laws and bylaws such as the GCC Trademark Law 2012, approving number of reference trade laws and regulations into binding GCC laws such as new common trade law, unified law of commercial agencies, common commercial registration law, GCC Commercial Fraud Control, GCC Consumer Protection law, GCC Competition Law, GCC Commercial Secrets Law, Unified Law for Supervision and Control of Insurance Activities, Unified Law of Auditing and Common Electronic Transactions law.

However, the barriers of trade do not lie in Tariff barriers (NTB), non-tariff barriers are stronger than tariff barriers, and in this regards the NTB have inhibited greater trade between the GCC states, for example a GCC railway has been mapped out but is yet to gain much traction, while other early plans for a combined value-added tax (VAT) were put on ice until recently, when the oil price crashed.

\subsection{Characteristics of the GCC economy}

There are many characteristics that shaped the economy and therefore the trade of the GCC countries. These are: (World Bank, 2010) ${ }^{1}$

1. The shared historical and cultural ties and aspire to develop a more diversified economic bloc over time.

2. High-income, hydrocarbon-based economies, the GCC countries acquired around (2\%) of the world GDP, although there are huge differences in the per-capita among the GCCC, for example the per-capita in Oman (16.1) thousand US\$ which is less than one fourth of Qatar (67.7) (see Table 1). However, there are suitable GDP growth rate, the per capita growth rate decline.

3. The GCC countries have accumulated large fiscal and current account surpluses in recent years. Public expenditure, derived primarily from oil revenue, has increased significantly, with a focus on developing the physical and social infrastructure required for private sector development. Other common structural features of the GCC economies include a young and rapidly growing labor force, and a large public sector and open immigration policies for temporary work as well as heavy reliance on foreign expatriate labor which poses a long-term challenge. The share of expatriates in the population runs as high as $80-90 \%$ for Qatar and the UAE, with somewhat lower shares in the other countries.

4. The social and political backgrounds of GCC countries exhibit many similarities. All GCC countries are traditional monarchies, with the state playing a visible role in economic activity.

5. Similar economic policies among GCC countries largely reflect their common circumstances include open economies with free trade and capital movements and an exchange rate pegged directly or indirectly to the US\$.

6. The degree of trade openness (the ratio of total exports and imports to GDP) varies and range from $73 \%$ in Kuwait to $158 \%$ in the UAE (see Table 1).

${ }^{1}$ WORLD BANK MIDDLE EAST AND NORTH AFRICA REGION Economic Integration in the GCCOCTOBER 2010 
7. The increased global focus on business environment indicators has successfully promoted reform and helped economic integration in a number of areas as ease of doing business.

Table 1

The Main Economic Indicators of the GCC Countries in 2017

\begin{tabular}{lccccccc}
\hline \multicolumn{1}{c}{ Country } & Bahrain & Kuwait & Oman & Qatar & Saudi Arabia & UAE & GCC \\
\hline Total Population & 1.4 & 4.0 & 4.7 & 2.3 & 32.2 & 9.3 & 53.8 \\
Percentage & 2.6 & 7.5 & 8.7 & 4.3 & 59.8 & 17.2 & 100.0 \\
Area & 0.8 & 17.8 & 309.5 & 11.6 & 2149.7 & 83.6 & 2673.1 \\
Percentage & 0.0 & 0.7 & 11.6 & 0.4 & 80.4 & 3.1 & 100.0 \\
GDP (Million US\$ & 32.6 & 119.9 & 71.9 & 173.9 & 688.4 & 383.8 & 1470.6 \\
\% of the World & 0.0 & 0.2 & 0.1 & 0.2 & 0.9 & 0.5 & 1.9 \\
\% of the GCC & 2.2 & 8.2 & 4.9 & 11.8 & 46.8 & 26.1 & 100.0 \\
GDP Per Capita & 22.9 & 29.6 & 16.2 & 67.7 & 21.3 & 41.4 & 27.2 \\
Annual Average Growth Rate & 2.0 & 2.3 & 1.8 & 2.7 & 1.8 & 2.0 & 2.0 \\
Annual Average Growth Rate Per Capita & -1.8 & -0.6 & -3.4 & -0.8 & -0.5 & 0.7 & -0.5 \\
\hline Source: calculated and collect form & & & & & & &
\end{tabular}

8. The total population is 54 million and the total area is 2673.1 thousand square Kilometer, most of this area is deserts and not suitable for agriculture. There are big differences in area and population of these countries, where Saudi Arabia is the biggest and the Bahrain is the smallest.

9. High income and big population as well as the foreign labors make the GCC a big market with high demand for all commodities.

10. In the recent years, GCC countries started to diversify their economies and gave emphasis on manufacturing, finance, transportation, education and tourism sectors. As a result of this economic diversification, non-oil sector had a higher contribution to economic growth than the oil sector during the 2003-2016.

\subsection{Trade inductors of GCC countries}

Table 2 shows the main indictors of the GCC countries trade during the 2017. The table indicates that the UAE is the biggest importer and exporter countries of the GCCC which exports and import about $45.2 \%$ and $49.4 \%$ of the total exports and imports of the GCC countries export and import. The second countries are the Saudi Arabia with $31 \%$ and $29.8 \%$ of the total export and imports. The smallest country is Bahrain with around $2 \%$ of exports and imports of the total exports and imports of the GCCC. Qatar, Kuwait and Oman share around 9.7\%, 7.9 and 4.2\% of the total exports of GCCC while they import around $7 \%, 6.8 \%$ and $5.1 \%$ of the total GCCC import. The table indicates that all GCC countries have positive trade balance. The share the total trade of the GDP varies from one county to another country, the percentage is around $127.9 \%$ of the GDP of the UAE while it is around $46.2 \%$ of the GDP of the S. Arabia, the other GCCC is around $65 \%$ of their GDP.

The terms of trade index are around $98.2 \%$ for Kuwait while it is exceeding $100 \%$ for the other GCCC, it reaches $450.5 \%, 296.3 \%$ and $131 \$$ for Qatar, UAE and S. Arabia. This indicates that Current value of exports (f.o.b.) was converted to dollars and expressed as a percentage of the base year (2000).

Table 3 shows the trade partners of the GCC region, the table indicates that the main importers of the GCC region are China, Japan and India with around (31.6\% of total) for each followed by Korea (7.8\%), United States of America (4.6\%), and Singapore (4.4\%) all around (48.6\%). other biggest Iran, Taiwan, United Arab Emirates, Thailand, Oman, Pakistan, Saudi Arabia, Iraq, Liechtenstein. However, the GCC countries contribute around only about $10 \%$. The main import partners are China, USA, India, Germany, United Arab Emirates, Japan and Saudi Arabia with about 50\% of the total imports of the GCC region followed by United Kingdom, Korea, Italy, Turkey, France, Viet Nam and Switzerland, Liechtenstein with around $20 \%$ of the total GCC region imports. 
Table 2

Main Indicators of Export and Imports of GCC Countries

\begin{tabular}{|c|c|c|c|c|c|c|c|}
\hline Indicator & Bahrain & Kuwait & Oman & Qatar & S. Arabia & UAE & GCC \\
\hline \multicolumn{8}{|c|}{ Exports } \\
\hline Value Billions of US\$ & 12.1 & 46.3 & 24.5 & 57.3 & 182.3 & 265.9 & 588.3 \\
\hline$\%$ of Total World & 0.1 & 0.3 & 0.2 & 0.4 & 1.1 & 1.7 & 3.7 \\
\hline$\%$ of GCC & 2.1 & 7.9 & 4.2 & 9.7 & 31.0 & 45.2 & 100.0 \\
\hline Number of Products & 221 & 219 & 193 & 165 & 249 & 257 & 257 \\
\hline Concentration Index & 0.4 & 0.7 & 0.6 & 0.5 & 0.7 & 0.3 & 0.5 \\
\hline Diversification Index & 0.7 & 0.8 & 0.7 & 0.8 & 0.8 & 0.5 & 0.6 \\
\hline Value Index of Exports & 193.1 & 236.8 & 223.5 & 496.7 & 225.5 & 533.6 & 330.6 \\
\hline Volume Index of Exports 2000 & 106.3 & 172.9 & 153.7 & 81.5 & 119.4 & 132.7 & 127.5 \\
\hline Unit Value Index of Exports & 181.6 & 137 & 145.4 & 609.4 & 188.9 & 402.2 & 293.7 \\
\hline Purchasing Power Index of Exports & 109.3 & 169.8 & 164.6 & 367.2 & 156.3 & 393.1 & 234.8 \\
\hline \multicolumn{8}{|c|}{ Import } \\
\hline Value Billions of US\$ & 8.7 & 30.8 & 23.3 & 32.1 & 135.9 & 225 & 455.7 \\
\hline$\%$ of Total World & 0.1 & 0.2 & 0.1 & 0.2 & 0.8 & 1.4 & 2.8 \\
\hline$\%$ of GCC & 1.9 & 6.8 & 5.1 & 7.0 & 29.8 & 49.4 & 100.0 \\
\hline Number of Products & 241 & 240 & 245 & 248 & 247 & 259 & 259 \\
\hline Concentration Index & 0.2 & 0.1 & 0.1 & 0.1 & 0.1 & 0.1 & 0.1 \\
\hline Diversification Index & 0.4 & 0.4 & 0.4 & 0.4 & 0.3 & 0.3 & 0.3 \\
\hline Value Index of Imports & 187.8 & 439.5 & 442.4 & 978.5 & 461 & 642.7 & 537.4 \\
\hline Volume Index of Imports & 106.3 & 315.2 & 325.7 & 723.3 & 319.6 & 473.5 & 416.9 \\
\hline Unit Value Index of Imports & 176.7 & 139.4 & 135.8 & 135.3 & 144.2 & 135.7 & 140.8 \\
\hline \multicolumn{8}{|c|}{ Total Trade } \\
\hline Total Trade & 20.8 & 77.1 & 47.7 & 89.3 & 318.2 & 490.9 & 1044 \\
\hline$\%$ of GCC & 2.0 & 7.4 & 4.6 & 8.6 & 30.5 & 47.0 & 100.0 \\
\hline$\%$ of GDP & 63.6 & 64.3 & 66.4 & 51.3 & 46.2 & 127.9 & 71.0 \\
\hline Trade Balance & 3.4 & 15.4 & 1.2 & 25.2 & 46.4 & 40.9 & 132.5 \\
\hline$\%$ of Imports & 38.7 & 50.1 & 5.1 & 78.6 & 34.2 & 18.2 & 29.1 \\
\hline$\%$ of GDP & 10.3 & 12.9 & 1.7 & 14.5 & 6.7 & 10.7 & 9.0 \\
\hline Terms of Trade Index & 102.8 & 98.2 & 107.1 & 450.5 & 131.0 & 296.3 & 208.6 \\
\hline
\end{tabular}

Source: UNCTAD database.

Table 3

GCC Trade Partners in 2017

\begin{tabular}{|c|c|c|c|c|c|}
\hline \multicolumn{3}{|c|}{ Export } & \multicolumn{3}{|c|}{ Import } \\
\hline Partner & $\%$ & Accu. $\%$ & Partner & $\%$ & Accu. $\%$ \\
\hline China & 10.9 & 10.9 & China & 14.8 & 14.8 \\
\hline Japan & 10.8 & 21.7 & USA & 10.3 & 25.1 \\
\hline India & 10.0 & 31.6 & India & 7.7 & 32.8 \\
\hline Korea & 7.8 & 39.5 & Germany & 5.2 & 37.9 \\
\hline USA & 4.6 & 44.1 & UAE & 4.6 & 42.5 \\
\hline Singapore & 4.4 & 48.6 & Japan & 4.4 & 46.9 \\
\hline Iran & 3.8 & 52.3 & Saudi Arabia & 3.7 & 50.7 \\
\hline Taiwan & 3.4 & 55.8 & United Kingdom & 3.2 & 53.9 \\
\hline UAE & 3.1 & 58.9 & Korea & 3.1 & 56.9 \\
\hline Thailand & 2.7 & 61.5 & Italy & 3.0 & 59.9 \\
\hline Oman & 2.4 & 63.9 & Turkey & 2.8 & 62.7 \\
\hline Pakistan & 2.3 & 66.2 & France & 2.5 & 65.3 \\
\hline Saudi Arabia & 2.3 & 68.5 & Viet Nam & 2.2 & 67.4 \\
\hline Iraq & 2.2 & 70.7 & Switzerland, Liechtenstein & 1.7 & 69.1 \\
\hline Switzerland, Liechtenstein & 2.1 & 72.8 & Thailand & 1.4 & 70.6 \\
\hline
\end{tabular}

Source calculated from UNCTAD data base

\section{GCC intra trade analysis}

Fig. 1 shows fluctuation in the percentage of the GCC region trade of the member countries form one year to another year, this reflects the variation in the trade between the member countries. Although there are some increase in the proportion of the GCC member countries compared with the rest of the GCC region, but only Bahraini and Omani's exports show significant increase while other GCC members show 
slight increase or negligible increase. The graph also shows that only the Bahrain's export shows a big proportion and big increase during the period 1995-2017, and the export increased to reach (45\%) of the total Bahrain's exports, which is a big increase after 2008 where the export of Bahrain compared with other GCC countries almost doubled.

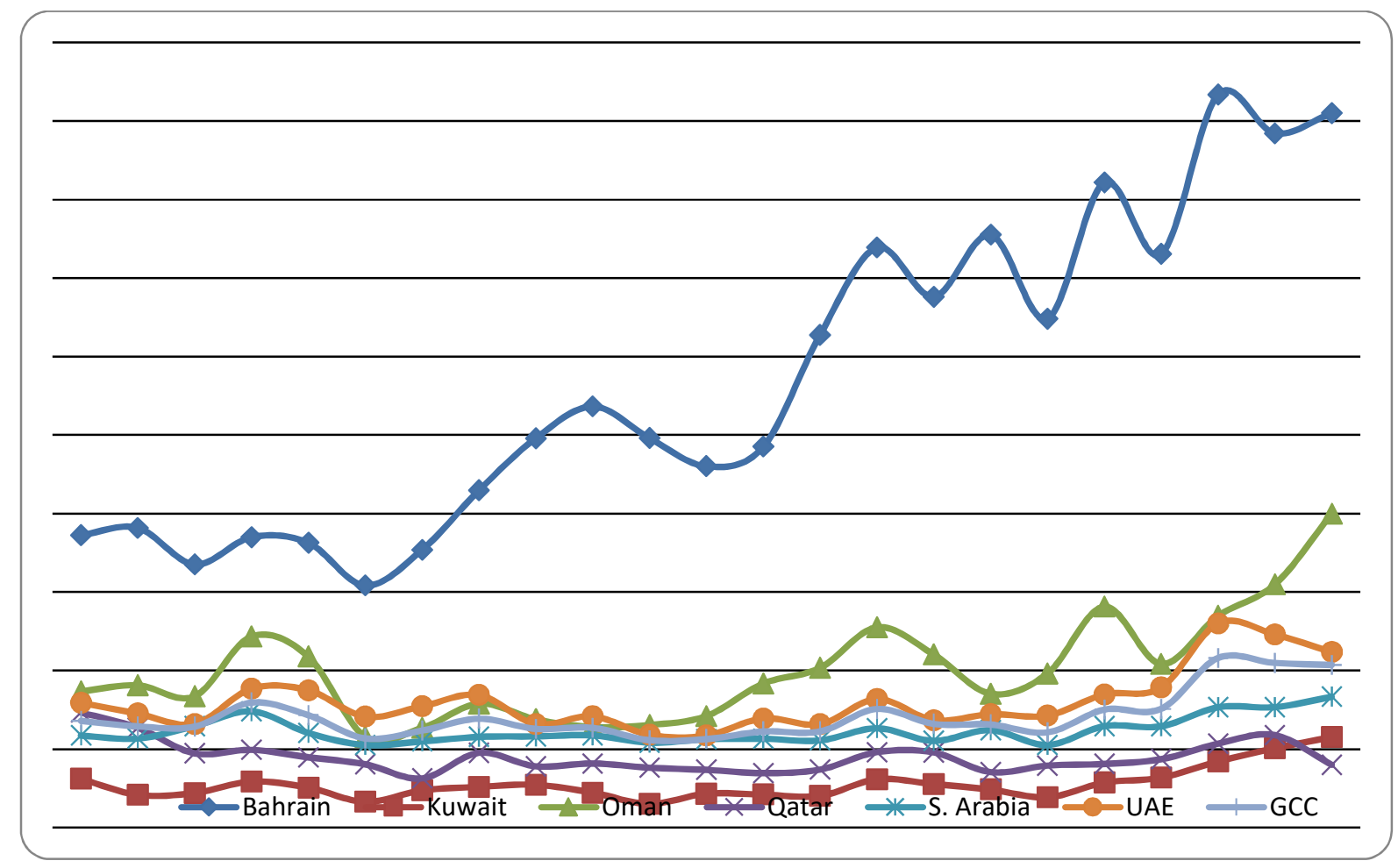

Fig. 1. The percentage of the export to GCCC from the total export

An Omani export compared with the other GCC members shows an increase of about $10 \%$ to be around $15 \%$ in 2017 , indicating that the Oman is the second region-oriented exporter. Other GCC members still export very small proportion of their export to GCC members.

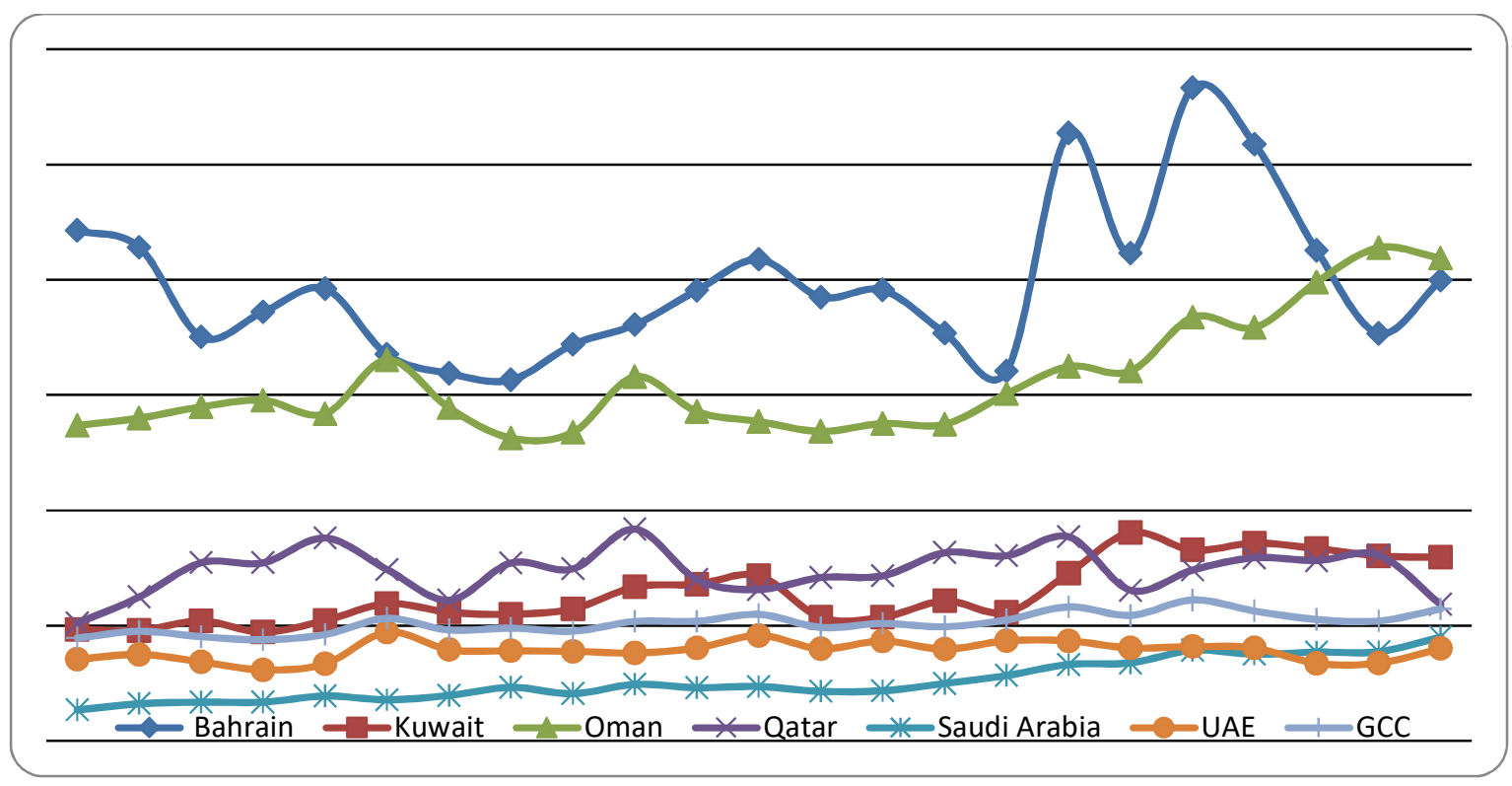

Fig. 2. Relative importance of the intra trade of the GCC member to rest of region 
Fig. 2 shows the relative importance of the import of the GCC members compared with the other members of GCC. The figure indicates the fluctuation of the proportion of the imports of the countries from other countries as group or as individual except for the Saudi Arabia imports which shows steady increase over the study period. In addition, the figure shows that Bahrain is the biggest importer from the GCC members, the total import of Bahrain is varying from year to year but still around $40-45 \%$ of the total Bahrain's import. However, there is a shape decrease of the proportion of the import of Bahrain form other GCC members after 2013, which shows big increase and the highest of the imports of Bahrain is from the GCC members. The second partner of the GCC countries that import from other members is Oman, the imports of Oman from the GCC members increased from around 30\% to $40 \%$ in 2017 of the total imports of Oman, which is the same as the Bahrain. Qatar is the third partner GCC region, the import of Qatar from other GCC members raging between 10-20\% of the total Qatari imports, showing unstable proportion. Other GCC member import less than $10 \%$ of its imports from the rest GCC members.

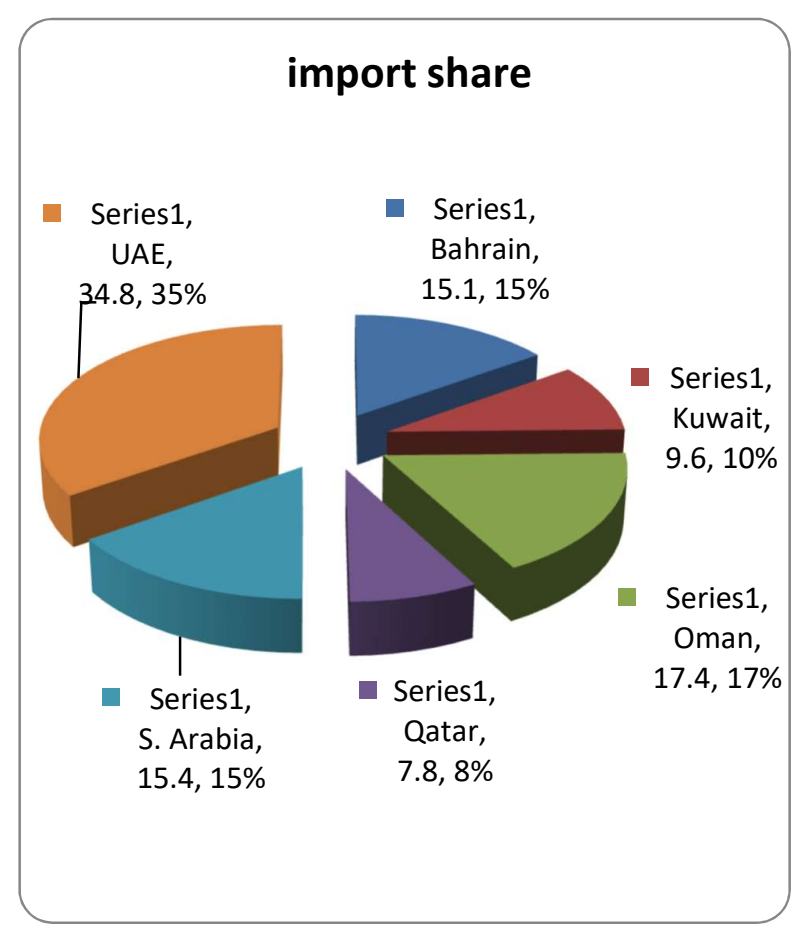

Share of GCC countries of intra import

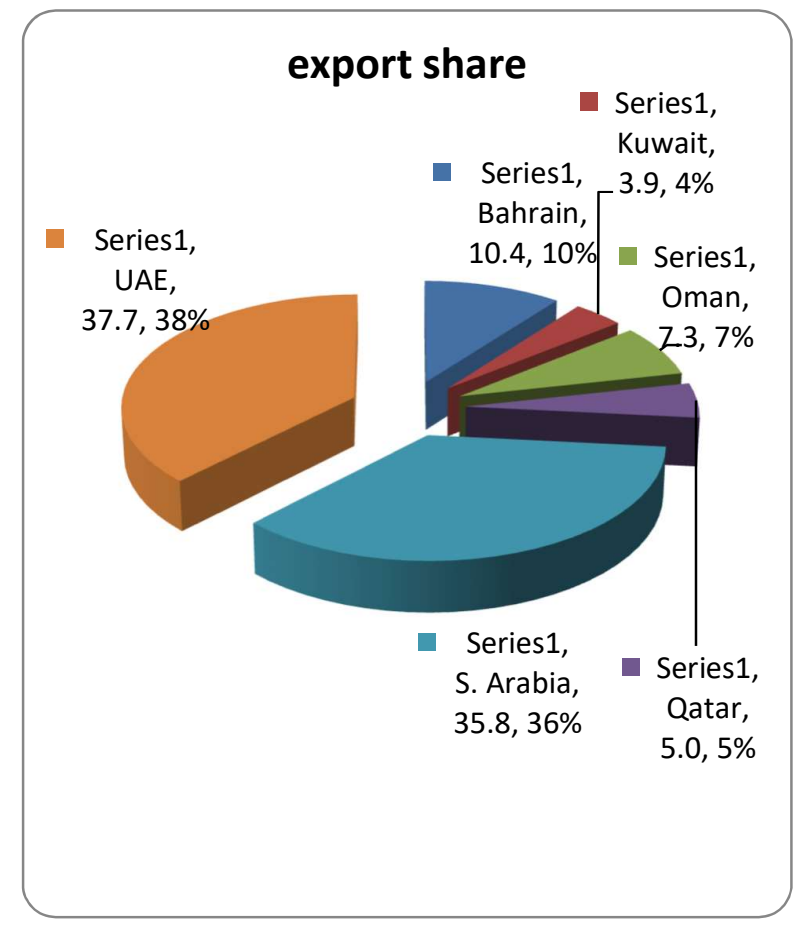

Share of GCC countries of intra export

Fig. 3. Share of GCC countries of intra import average of 1995-2017

Fig. 3 demonstrates the average shares of GCC member trade of GCC region intra trade. The figure indicates that the United Arab Emirates shared the height percentage of the intra trade between the GCC region with about $35 \%$ of the GCC intra import and $38 \%$ of the GCC intra export. Saudi Arabia is the second contributor to the intra GCC trade with $36 \%$ of the intra export and $15 \%$ of the intra import. Although Bahrain's trade is GCC region-oriented trade it shares only $15 \%$ and $10 \%$ of the total intra import and export, respectively. Oman comes in the second place in sharing the GCC intra import and the fourth place with $17 \%$ and $7 \%$ of the total GCC intra-import and export, respectively. Kuwait and Qatar share $10 \%$ and $8 \%$ of the GCC intra import and $4 \%$ and $5 \%$ of the total GCC intra export. 


\section{Trends of the intra-trade among GCC countries}

in order to explore the impacts of the three stages of the intra trade among the GCC countries during the period 1995-2017 and considering that there are three distinguished stages in the history of the trade arrangements between the GCCC, those are before 2002, 2003-2007 and after 2008, the study will compare between these three periods. Linear regression of imports and exports are run including dummy variable explained earlier. The dummy variable for the GCC customs union stage during 2003-2008 (d2) and third stage common market stage after 2008 (d3) for both intra exports and imports. The results of the regression are shown in Table 4 and Table 5.

Table 4

Results of Trend Regression Analysis of GCC Intra-Trade Exports

\begin{tabular}{|c|c|c|c|c|c|c|c|c|}
\hline Country & Parameter & Intercept & YEAR & $\mathrm{d} 2$ & $\mathrm{~d} 3$ & $\mathrm{~F}$ & Sig. & $\mathrm{R} \mathrm{Sq}$. \\
\hline \multirow{2}{*}{ Bahrain } & Coeff. & -5799.6 & 2.91 & -1.57 & 15.50 & 63.5 & 0.000 & 0.89 \\
\hline & P-value & 0.000 & 0.000 & 0.840 & 0.264 & & & \\
\hline \multirow{2}{*}{ Kuwait } & Coeff. & -2539.9 & 1.27 & -2.83 & 2.52 & 52.6 & 0.000 & 0.88 \\
\hline & P-value & 0.002 & 0.002 & 0.379 & 0.655 & & & \\
\hline \multirow{2}{*}{ Oman } & Coeff. & -4349.3 & 2.18 & -5.52 & 10.08 & 30.5 & 0.000 & 0.80 \\
\hline & $\mathrm{P}$-value & 0.027 & 0.027 & 0.511 & 0.495 & & & \\
\hline \multirow[t]{2}{*}{ Qatar } & Coeff. & -1809.3 & 0.91 & 1.94 & 24.08 & 29.3 & 0.000 & 0.79 \\
\hline & P-value & 0.271 & 0.270 & 0.792 & 0.074 & & & \\
\hline \multirow{2}{*}{$\begin{array}{l}\text { Saudi Ara- } \\
\text { bia }\end{array}$} & Coeff. & -15546.7 & 7.80 & 10.13 & 34.76 & 30.2 & 0.000 & 0.80 \\
\hline & P-value & 0.021 & 0.020 & 0.721 & 0.488 & & & \\
\hline \multirow{2}{*}{ UAE } & Coeff. & -45630.7 & 22.85 & -105.98 & -87.69 & 61.4 & 0.000 & 0.89 \\
\hline & P-value & 0.00 & 0.00 & 0.01 & 0.19 & & & \\
\hline \multirow{2}{*}{ GCC } & Coeff. & -75675.5 & 37.92 & -103.83 & -0.75 & 81.0 & 0.000 & 0.92 \\
\hline & P-value & 0.00 & 0.00 & 0.14 & 1.00 & & & \\
\hline
\end{tabular}

Table 5

The Results of Trend Regression Analysis of GCC Intra-Trade Import

\begin{tabular}{llccccccc}
\hline Country & Parameter & Intercept & year & $\mathrm{d} 2$ & $\mathrm{~d} 3$ & $\mathrm{~F}$ & Sig. F & R Sq. \\
\hline \multirow{2}{*}{ Bahrain } & Coefficients & -154.32 & 0.08 & 1.71 & 2.52 & 10.9 & 0.000 & 0.575 \\
& P-value & 0.533 & 0.529 & 0.140 & 0.194 & & & \\
\hline \multirow{2}{*}{ Kuwait } & Coefficient & -472.99 & 0.24 & -0.42 & 0.11 & 61.9 & 0.000 & 0.893 \\
& P-value & 0.000 & 0.000 & 0.398 & 0.897 & & & \\
\hline \multirow{2}{*}{ Oman } & Coefficients & -1039.2 & 0.52 & -1.65 & 0.22 & 55.5 & 0.000 & 0.881 \\
& P-value & 0.001 & 0.001 & 0.164 & 0.909 & & & \\
\hline \multirow{2}{*}{ Qatar } & Coefficients & -266.09 & 0.13 & 0.72 & 1.98 & 44.2 & 0.000 & 0.855 \\
& P-value & 0.056 & 0.055 & 0.246 & 0.065 & & & \\
\hline \multirow{2}{*}{ Saudi Ara- } & Coefficients & -1061.7 & 0.53 & -1.71 & 1.09 & 55.3 & 0.000 & 0.881 \\
bia & P-value & 0.001 & 0.001 & 0.201 & 0.622 & & & \\
\multirow{2}{*}{ UAE } & Coefficients & -1783.89 & 0.89 & -0.01 & 3.13 & 67.3 & 0.000 & 0.900 \\
& P-value & 0.001 & 0.001 & 0.995 & 0.378 & & & \\
\hline \multirow{2}{*}{ GCC } & Coefficients & -4778.14 & 2.39 & -1.36 & 9.05 & 69.2 & 0.000 & 0.903 \\
& P-value & 0.001 & 0.001 & 0.809 & 0.345 & & & \\
\hline
\end{tabular}


The results of the regression show that the trend represented by the year is significant for all countries expect for Qatar and the two dummy variables' coefficients are insignificant. In other words, there is no impact of the third stage which began after 2008 while the dummy variable for second stage is only significant for the export of the United Arab Emirates, this may reflect that United Arab Emirates benefits form the measure taken to affiliate the trade between the GCC members and the free trade zone located in the United Arab Emirates which can supply to all the regions with goods.

The table shows that there was no impact of trends represented by the year on the imports of Bahrain and Qatar to the other members of GCC and there are no effects of the stages of the trade arrangements between GCC members on the intra imports of those countries from the GCC region.

\section{Conclusion and Recommendation}

The study has pointed that Bahrain is the biggest importer and exporter from the GCCC where more than $45 \%$ of the Bahrain trade was with the GCCC, while other countries export and import were less than $10 \%$ of the total trade of each countries. Oman is the second exporter and importer with GCCC followed by United Arab Emirates, Saudi Arabia, Qatar and Kuwait respectively.

The trade between the GCCC consists very small proportion from the total trade of the GCCC, and shows increasing trends over years of the study period, however the analysis shows that there was no impact of the trade arrangements between the GCCC in the case of the stage of the GCC customs union during 2003-2008 and the stage of common market after 2008 on the progress of the trade between these countries. This may due to that fact that most of the GCCC export oil and gas and the smaller productions of these countries are associated with logistics issues. It is recommended that the GCC leadership put more and great efforts on diversification the economy of these countries and build integrated industries rather than the common production or relying on other countries to meet their needs. This implies that common economic projects and industries should be implemented.

\section{Acknowledgement}

The authors would like to thank the anonymous referees for constructive comments on earlier version of this paper.

\section{References}

Akhtar, S., \& Rouis, M. (2010). Economic integration in MENA: the GCC, the Maghreb, and the Mashreq.

Ayalon, A. (1992). Middle East Contemporary Survey, Volume Xiv: 1990 (Vol. 14). The Moshe Dayan Center.

Dadush, U., \& Falcao, L. (2009). Regional arrangements in the Arabian Gulf. Universitäts-und Landesbibliothek Sachsen-Anhalt.

GCC (20007). the 28th Session of the Supreme Council in Doha, December 2007.

GCC (2017) website

Insel, A., \& Tekce, M. (2010). Econometric analysis of the bilateral trade flows in the Gulf Cooperation Council countries.

Nechi, S. (2011). Determinants of trade flows among GCC countries: Potentials, limitations, and expectations. World Review of Business Research, 1(5), 91-109.

Peterson, E. R. (1988). The Gulf Cooperation Council: Search for unity in a dynamic region (pp. 195201). Boulder and London: Westview Press.

Ravi, N. (2013). Intra regional trade among Gulf Cooperation Council. The Macrotheme Review, 2(3), 108-114.

Sahib, A. S. A., \& Kari, F. (2012). Analysis of Intensity of Intra-Regional Trade in GCC Countries, 19982008. International Journal of Trade, Economics and Finance, 3(3), 204. 
World Bank Middle East and North Africa Region Economic Integration in the GCC October 2010 http://go.worldbank.org/OFWIDAGNO0

UNCTAD (2017). Data base on the website.

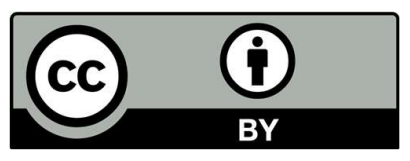

(C) 2019 by the authors; licensee Growing Science, Canada. This is an open access article distributed under the terms and conditions of the Creative Commons Attribution (CCBY) license (http://creativecommons.org/licenses/by/4.0/). 